neighbourhoods except the most thriving and well-to-do? They will appear grotesquely untrue to the great majority in all the poorer districts of the country. I know from my own experience that not a few derive all their income from such sources. Again, we are told that at the present time onethird of the profession hold public appointments. As the vast majority of them are only part-time officials, who would probably not desire to give up private practice, the whole of this large body would run the risk of being deprived of their offices. Whether they would be satisfied by the advantage likely to be derived by the clearance of many of their competitors out of the field of private practice is more than doubtful. Many would prefer to compete with their present professional neighbours on equal terms rather than as wholetime State doctors.

It is admitted by the writers there is one thing that can militate against the Minority view of the private practitioner's future, which is the crux of the whole question. "If there is to be a gratuitous State service, or one without any but nominal charges, then the medical profession must have nothing more to say to the Minority proposals." Here we are on common ground. It is on account of this almost certain result of such a scheme that I trust the profession will adhere to its present attitude of leaving the Minority proposals severely alone. The writers of the " appeal" frankly admit this danger, but point out an infallible preventive. Until they can show us something better than "the Consistent Code" to recover all charges from those proved able to pay for gratuitous medical services, in my opinion they will have little chance of converting the medical profession to their views. I would specially quote the following: "The point to be enforced is that there is no inherent difficulty in recovering the cost of treatment from patients. It has been done already to a large extent. Given a properly framed code and the adequate machinery, it will be as easy as the collection of rates and taxes to restrict our medical service to the destitute by this process of charge and recovery."

The italics are my own and will possibly suggest a.good deal to thoughtful readers. For myself I would like to say I have found considerable inherent difficulties in recovering medical charges from patients admittedly not destitute. What might be done by "properly" framed codes and "adequate" machinery I cannot tell, but our present legal system is in my opinion hopelessly inadequate. That its recovery might be as easy as the recovery of rates and taxes from the destitute I am willing to admit, but I did not know that such recovery was easy. I am quite at one with the writers as to the restriction of gratuitous medical relief to the destitute, but I have gravely misread the Minority Report if it was the intention of the Minority Commissioners to restrict such relief to the destitute.

I am, Sir, yours faithfully,

July 23rd, 1910 MAJOR GREENWOOD.

\section{THE SUPPRESSION OF QUACKERY.}

\section{To the Editor of THE LANCET.}

SIR,-The letter of Mr. Macleod Yearsley in ThE LANCET of July 23rd is to the point, and one may hope that his proposal to found a society for the suppression of quackery may meet with an enthusiastic reception amongst our profession. For some time past I have had the intention of forming an organisation of the kind and should be glad to join forces in so excellent an object. As regards the petition to the General Medical Council, I may say that a petition addressed by myself to that body met with no better fate than Mr. Yearsley's. After a prolonged study of various Acts of Parliament and other documents I formed an opinion that there is ample legislation in existence for the suppression of quacks and quackery-at any rate, so far as London and ten miles around is concerned. Absolute summary powers were conferred on the Royal College of Physicians of London for that purpose, and were exercised by that body intermittently for some hundreds of years. The rights of the College were reiterated in every subsequent Medical Act up to the short amending Act of 1860, wherein the College re-affirmed its charter rights but abolished the "elects" whose duty it was to administer the penal clauses. Only a year or so ago the College asserted those rights once again in protesting against the proposed charter of the
British Medical Association. It has been held in some quarters that the powers of the College were merged in those of the General Medical Council by the Act of 1858.

Now all this is absolutely pertinent to the constitution of the General Medical Council. Stringent statutory powers against quackery exist, and if they are not in the hands of the Council they are in the hands of the College and vice versá. My petition, however, was thrown out by the Executive Committee of the Council, and the discussion of an allimportant matter was thus indefinitely shelved. If the penal powers of the College were absorbed by the Council, then the contention that the Act of 1858 conferred only limited powers upon that body falls to the ground. If not, the duty rests with the Royal College of Physicians, despite the fact that the small amending Act of 1860 abolished their machinery-their fundamental duty remains unrepealed. If the Council refuses to discuss so vital a matter, should not the British Medical Association approach the Privy Council directly on the point?

It is clearly better to act on existing laws than to attempt to get new ones. Lastly, I may say that as a layman I secured legal advice and opinion as to the scope and meaning of many of the Medical Acts and other documents concerned. What I asked the Council specifically to do was to obtain an authoritative legal opinion as to the existence of special legislation adequate for the suppression of quackery, and as to its present whereabouts as regards administration.

Surely the public and the medical profession are entitled to ask from the General Medical Council for more light upon matters so closely connected with their constitution. I am, Sir, yours faithfully,

Welbeck-street, W., July 25th, 1910. DATID WALSH.

To the Editor of THE LANCET.

SIR, - It is to be hoped that Mr. Macleod Yearsley will not limit the aims of the society he proposes to the suppres. sion of quack advertisements, but that it will encieavour to extend the powers of the General Medical Council, which have long required reformation. It is surely not impossible to obtain for it powers similar to that possessed by the Incorporated Law Society. Then the views of the profession might be more firmly enforced when legislation affecting its interests was under consideration. The remuneration of all county medical officers of health might then more nearly approximate that of county court judges and the district medical officer's salary equal that of a revising barrister: the work, responsibility, and the issues at stake would surely commend it. Misleading quack advertisements would then, perhaps, cease to offend, and the "Drs." (with the qualifying inverted commas) would

"Fold their tents like the Arabs, And as silently steal away."

I am, Sir, yours faithfully, W. J. ERNELY SUMPTER, M.D.

Sheringham, July 26th, 1910

\section{METALS AND MICRO-ORGANISMS. \\ To the Editor of THE LANCET.}

SIR,-Upon pp. 1014 and 1015 of your issue of April 9tb, 1910, appears an abstract of a communication to the Royal Society by Dr. A. C. Rankin, demonstrator in bacteriology at McGill University. This abstract, entitled " Metals and Micro-organism\&," seems to me somewhat contradictory in its statements, and also describes as a "suspicion" what has long been recognised as a fact. The points to which I wish to draw attention are as follows:

The statement is made that water containing the typhoid bacillus and kept in a clean copper bowl becomes sterile. Almost immediately below occurs the statement that relatively large areas of pure zinc exposed in water contaminated with colon bacilli bring about recognisable but not extreme destruction of bacteria; and that aluminium and copper under similar circumstances have no perceptible effect. think it is clearly evident that these two statements are diametrically opposed; and later in this abstract these two conditions regarding toxicity again seem to be in opposition.

Rather extensive work along these lines has been carried on in this department by Dr. Geo. T. Moore and myself and reported in Bureau of Plant Industry Bulletins Nos. 64 
and 76, entitled "A Method of Destroying or Preventing the Growth of Algæ and Certain Pathogenic Bacteria in Water Supplies" (issued May 7th, 1904), and "Copper as an Algicide and Disinfectant in Water Supplies" (issued April 5th, 1905). We have very clearly shown the sterilising power of copper upon the colon bacillus and typhoid bacillus and the cholera spirillum. In the case of copper at least there can be no doubt that the toxicity of the metal or the salt is due to the ion, and in my experiments $I$ have found carbon dioxide rather than oxygen to be an important factor limiting the destruction of bacteria. Under separate cover I am sending to you a publication entitled, "The Effect of Oopper upon Water Bacteria," by Mr. T. D. Beckwith and myself, that deals with some experimental work upon this subject. I am, Sir, yours failhfully,

KARL F. KELLLRMAN

Physiologist in Charge, United States Department of Agriculture, Bureau of Plant Industry (Soil Bacteriology and Water Purification

Washington, D.C., July 12th, 1910. Investigations).

\section{OPHTHALMIA NEONATORUM. To the Editor of THE LANCET.}

SrR,-May I point out that you have omitted to include this town as one of the districts in which ophthalmia neonatorum is compulsorily notifiable? The Order of the Local Government Board came into force on May 18th last. We are, therefore, entitled to rank ourselves with Chester, Stoke-on-Trent, and the 1.5 States of the United States of America! Credit to whom credit is due, Mr. Editor. I am, Sir, yours faithfully,

J. HEDLEY MARSH, Medical Omeer of Fealth.

Macclesfield, July 23rd, 1910.

\section{GRAIN ITCH.}

To the Editor of THE LANCET.

Sir,-In an annotation in THE LANCET of July 9th an account was published of "Grain Itch" with a request to know whether the disease occurred in this country. Whilst acting as locum tenens in Somersetshire a patient of mine was employed during harvest to carry bundles of straw into a loft. This was followed the next day by a pustular eruption on the arms, which eventually subsided into congested-looking bluish spots which irritated. I did not examine the straw, so cannot furnish any further details of the case. I am, Sir, yours faithfully,

County Hospital, Guildford, July 23rd, 1910. H. J. FARDON.

\section{THE PETROL REBATE.}

\section{To the Editor of THE LANCET.}

SIR,-My experience exactly tallies with that of your correspondent " 8 H.P.," and it seems evident that the conditions attaching to the claim for rebate are intentionally so framed as to render its recovery impossible. The Excise officer to whom I applied pointed out, in the most courteous terms, that the form of claim supplied by his department (which I had duly filled up) contains the words "on which the full duty has been paid to the Cronn" (my italics); and that there is more in this wording than meets the non-legal eye of the average medical motorist. It seems that proof is necessary (in the case of every tin of petrol used during the specified period of about eight months) of payment of full duty (1) by the consumer to the retailer ; (2) by the retailer to the manufacturer; and (3) by the latter to the Crown; and it must be shown that this last payment by the manufacturer actually reached the national coffers!

I am, Sir, yours faithfully,

July 23rd, 1910.

TWO CYLINDER.

Mr. Vaughan Grey's matinée in aid of Prince Irancis of Teck's appeal on behalf of the Middlesex Hospital, which was to be given at the Brudoir Theatre, Pembroke-gardens, to-day, Fridav, July 29th, was unavoidably postponed until Thursday, Nov. 10ch. We are asked to state that all tickets issued for July $29 \mathrm{th}$ will be available on the latter date.

\section{MANCHESTER.}

\section{(From OUR OWN CoRRespondenT.)}

\section{Ashby Memorial Soholarship.}

THE Ashby Memorial Scholarship of the Manchester University was founded as a memorial of the late Dr. Henry Ashby for the promotion of the study of the diseases of children, to which he had devoted his life's work. This year two of the aspirants have been adjudged equal, one being Hugh T. Ashby, M.B., B.C. Oantab., M.R.O.P. Lond., the son of the late Dr. Ashby, and the other $C$. P. Lapage, M.D. Vict., M R O.P. Lond., Dr. Ashby graduated at Cambridge in 1904 with honours in the Natural Sciences Tripos, and in 1908 became M. B. Dr. Lapage gained the John Henry Agnew scholarship in diseases of children in 1901, graduated in medicine in the Victoria University in 1902, and obtained the M.D. in 1905. He is now lecturer in school hygiene in the University. The Dauntesey Medical Scholarship has been awarded to Lily Allan, the Platt Biological Exhibition to $R$. G. Livens, and the University Prize in Medicine to $A . G$. Bryce.

\section{Hope Hospital.}

The Salford guardians appear to have a good deal of trouble with the hospital at Hope. At their recent meeting the report of the infirmary committee mentioned that there was a request from the medical superintendent for the addition of two more nurses and one house sister to the staff. One can understand the startling effect that this request would have on the guardians, who think of the rates as well as of the poor, and it is not perhaps surprising that a resolution was moved not to accede to the request. Happily, however, an amendment was carried adjourning the consideration of the question until the next meeting. This will give time to consider the grounds for the request. It is scarcely to be imagined that the experienced medical superintendent would ask for such a reinforcement of the nursing staff without sufficient reason, and the adjournment will give time for an appeal from guardians startled to guardians calm and properly informed. Another matter adjourned was the question of a new dietary for the inmates.

\section{Health of Lanoashire Scholars.}

The recent statements made at the meeting of the Lancashire education committee at Preston on July 18th are sufficiently alarming as regards the health of the children. It is a serious matter that of the 60,000 examined 12,000 should be suffering from skin disease, while 11,000 had defective vision, many of whom were without spectacles. Whether any of the defective vision is due to small type or bad print in the school-books is not stated, but it is, of course, eminently desirable that this source of mischief should be avoided.

\section{Hospital Sunday Fund.}

It was decided at a meeting of the supporters of this Fund, the Lord Mayor, Mr. Charles Behrens, in the cbair, that $£ 4100$-i.e., $£ 700$ more than last year-should be distributed among the medical charities of Manchester and Salford. The following statement shows the apportionment, and cheques for the several amounts have been issued to the respective institutions by the treasurer (Mr. John F. Haworth, J.P.): Royal Infirmary, £1264 16s. 1d. ; Children's Hospital, $\$ 500$ 0s. 7d.; Ancoats Hospital, £331 1s. 6d.; Sick Poor and Private Nursing Institution, £328; St. Mary's Hospitals, £277 18s. 11d. ; Hospital for Consumption, $£ 258$ 18s. 10d. ; Salford Royal Hospital, £233 2s. 11d.; Roval Eye Hospital, £210 19s $7 d$.; Hospital for Incurables, $£ 1997 s .3 d$. ; Northern Hospital, £134 16s. 7d. ; Hnspital for Skin Diseases, $£ 104$ 17s. 10d.; Victoria Memorial Jewish Hospital, £104 11s.; Ear Hospital. £40 19s. 2d.; Dental Hospital of Mancbester, £36 4s.4a.; Hulme Dis. pensary, £21 17s. 4d.; Greengate Dispensary, £16 16s. 6d.; Chorlton-on-Medlock Dispensary, £13 9s. 1d.; Christie Hospital, £11 2s. 1d.; Lock Hospital, £9 13s. 11d.; Homonpathic Institution, £1 6s. $6 d$.; total $£ 4100$. July 26 th. 